\title{
Sexual Transformation in the Swordtail Fish Xiphophorues helleri under the Influence of Hydrocortisone Hormone and Temperature
}

\author{
Original \\ Article
}

Ali A. A. AL-Ali and Muneerah A. Ibrahim

Department of Biology, College of Education for Pure Science, University of Basrah, Iraq

\begin{abstract}
Background: Sex in vertebrates is generally determined by two mechanisms: Genetic Sex Determination (GSD) and Environmental Sex Determination (ESD).

Aim: This study evaluated the identification of sex in fish by external factors such as temperature, as well as the role of hormones, such as corticosteroids. The mature Xiphophorus helleri were obtained from aquarium fish shops in Basrah Governorate. The experiments were designed by conducting two experiments involving 40 fishes, the first was in the summer from 30 July 2017 to 28 August 2017 under laboratory temperature $\left(28-37 \mathrm{C}^{\circ}\right)$. The water temperature was between $(28$ $34 \mathrm{C}^{\circ}$ ) and 14-hour lighting. The second experiment was in the winter from 3 December 2017 to 2 January 2018 under laboratory temperature $\left(17-21 \mathrm{C}^{\circ}\right)$ and a water temperature between $\left(16-21 \mathrm{C}^{\circ}\right)$ and an 11 hours lighting. The mature fishes were divided into two groups, each containing 20,12 female $(1.63 \mathrm{~g})$ and 8 male $(2.72 \mathrm{~g})$, placed in 60 -litre glass basins with ventilators and thermometers to measure the water temperature. The first was considered as a control group for both the summer and the winter experiments. The second group was treated for a month with the Hydrocortisone Sodium Succinate (Roxcortisone) with a concentration of $2.5 \mathrm{mg} / 1$.

Results: Showed that the phenotypic changes in the female X. helleri treated with Hydrocortisone and temperature (28$\left.34^{\circ} \mathrm{C}\right)$ and $\left(16-21^{\circ} \mathrm{C}\right)$ were caused by gradual elongation of the ventral part of the caudal fin, where the elongation reached the significant limit $(6.08 \pm 0.03-1.52 \pm 0.83)$ between females treated in the summer and winter groups respectively and the females of the control group. There was also elongation in the female groups treated in summer and winter but did not reach the significant limit at the probability level $(\mathrm{P} \leq 0.05)$.

As the results of the microscopic examination for the ovaries of $\mathrm{X}$. helleri treated with Hydrocortisone and temperature (28$34 \mathrm{C}^{\circ}$ ) showed the presence of some ovaries containing large numbers of atrophy eggs, ovaries containing lysis embryos and eggs, while other ovaries contained complete growth embryos but dead. As for the ovaries of other female group treated with Hydrocortisone and the temperature of (16-21Co), they were characterized by containing many embryos which are dead and some of them appeared with various congenital malformations, such as those with a puffy head in the cavernous region. It was also noted that some embryos had sprains in different areas of the spine.

Conclusion: The hydrocortisone act as a promote to sexual transformation under different temperatures. This sexual transformation is done on one of the external features only, that is the emergence of the sword in females.
\end{abstract}

Received: 21 June 2019, Accepted: 20 September 2019

Key Words: Hydrocortisone, sexual transformation, temperature, X. helleri.

Corresponding Author: Ali Abdalhassan ALali, PhD, Department of Biology, College of Education for Pure Sciences, Basrah University, Iraq, Tel.: +964 7710850383, E-mail: ali43.bas@gmail.com

ISSN: 1110-0559, Vol. 43, No. 1

\section{INTRODUCTION}

Sex in vertebrates is generally determined by two mechanisms: Genetic Sex Determination (GSD) and Environmental Sex Determination (ESD). Genetically determined sex takes place when sex is determined early in fertility throughout genetic factors (sex chromosomes) inherited from parents, which differ in males from females where sex chromosome in the female is XX, while in the male is XY. Environmental Sex Determination, on the other hand, is represented by external circumstances that determine the fish's sex during its early formation ${ }^{[1,2]}$.

Sex determination in Poikilothermic vertebrates, such as reptiles, amphibians, and fish, is strongly influenced by environmental factors ${ }^{[3]}$. Numerous studies indicate that sex in bonefish is influenced by environmental factors such as temperature, $\mathrm{pH}$, and population density that may alter sex in fish ${ }^{[4,5]}$.

Temperature is an important environmental factor of sex determination in bonefish, especially in an early stage which is critical. The age stage in which sex is influenced by temperature is referred to as the Thermo Sensitive Period (TSP).

Larvae and young female stage in bonefish is one of the periods mostly affected by temperature in determining or changing the sex ratio. It was noticed that there was an increase in the male ratio of larvae and young female 
sea bass fish of Dicentrarchus labrax L., which reached $100 \%$ when breaded in temperature of $19-22 \mathrm{C}^{[6]}$. It was also found that when the bonefish larvae of Paralichthys olivaceus Japanese flounder was breaded in high or lowtemperature water, its females could reverse their (Sexreversal) $)^{[7,8]}$.

Bonefish have three strategies that can be observed when they change their sex. They are: Protogynous, in which females are transformed into males (this mechanism is common in coral fish), Protandrous, in which males are transformed into females (as in anemonefishes), and Bidirectional sex change, where sex can change in both directions, as in Gobies ${ }^{[1]}$. The change in the previous strategies includes behavioural modification, genital restructuring and changes in appearance ${ }^{[9,10]}$.

Some hormones play an important role in the process of sex differentiation in vertebrates. Among them are the sex hormones that are primary in the process of sexual differentiation in the early stages of growth: Androgen hormone stimulates male differentiation, while Estrogen hormone stimulates female differentiation ${ }^{[11]}$. These hormones, specifically male ones, have the ability to reverse or alter sex in fish. Angus and Peoples ${ }^{[12]}$ found that the treatment of Mosquitofish Gambusia affinis with Androgen (11-Ketotestosterone) lead to the appearance of some male phenotypic traits represented by the formation of Gonopodium in the anal fin.

Corticosteroids are one of the most important hormones in the reproductive process. Certain levels of cortical hormones produce a balance in the function of the gonads. It was found that when Cortisol hormone levels increase due to stress, they can cause pregnancy loss or have a negative effect on fertilization ${ }^{[13,14,15]}$.

Corticosteroids also have an active role in the process of sexual transformation or sex-reversal in bonefish. Yamaguchi et al. ${ }^{[16]}$ clarified the Cortisol hormone induction of the adult female of Japanese flounder and the transformation into males, when treating fish larvae with Cortisol mixed with nutrition of three concentrations of 1,10 and $100 \mathrm{mg} / \mathrm{g}$ at $18 \mathrm{C}$ from day 30 to day 100 after hatching (this period is necessary for gender differentiation in this kind of fish), then the larvae completed their growth to the age of 10 months, reaching puberty.

The X. helleri is aquarium fish, because easy breeding in the laboratory and short life cycle its has been used in scientific research in Iraq as a model for laboratory experiments.

Because only some studies point to the natural sexual transformation in the female swordfish on the one hand, and the role of the different environmental factors and corticosteroids in this phenomenon, on the other hand, the current study aims to investigate the possibility of stimulating sexual transformation in the laboratory mature females of X. helleri under the effect of Hydrocortisone hormone and different temperatures. This may be economic importance in the breeding of other fish, and may warn the breeders of the loss of one the sexes in the event of any changes in environmental factors, which may be reflected on the fish physiology and lead to sexual transformation.

\section{MATERIALS AND METHODS}

\section{Providing Fish Samples(males and females) and Breeding}

The mature fish of Xiphophorus helleri were obtained from the aquarium fish shops in Basrah Governorate and transferred to the Chamber of Animal Husbandry at the Animal House of Department of Biology / Collage of Education for Pure Sciences by oxygenated plastic bags. The fish were then placed in glass aquariums (200 liters) filled with RO water, equipped with continuous water ventilators and waste and residue purifiers, temperature between $\left(25-28 \mathrm{C}^{\circ}\right)$ and salinity (0.892) PPT. The fish were then fed mixed leafy vegetables (vegetarian-animal) and dried worms and left for two weeks to adaptation with these conditions.

\section{Exposure of $X$. helleri (male and female) to different temperatures and Hydrocortisone.}

Two experiments were conducted: the first was in the summer from 30 July 2017 to 28 August 2017 under laboratory temperature $\left(28-37 \mathrm{C}^{\circ}\right)$, water $\left(28-34 \mathrm{C}^{\circ}\right)$ and 14 hours of lighting, and the second was in the winter from 3 December 2017 to 2 January 2018 under laboratory temperature $\left(17-21 \mathrm{C}^{\circ}\right)$ and water $\left(16-21 \mathrm{C}^{\circ}\right)$ and 11 hours lighting.

The fish (they were 40) were divided into each experiment into two groups, each containing 20 fish 12 females $(1.63 \mathrm{~g} \pm 0.5)$ and 8 males $(2.74 \mathrm{~g} \pm 0.2)$. They were placed in 60-liter glass aquariums equipped with continuous ventilation, a thermometer to measure water temperature as well as a mercury thermometer to measure laboratory temperature. The first group was treated as a control group for both summer and winter experiments, while the second group was treated with the Hydrocortisone (Roxcortisone) Sodium Succinate manufactured in the Netherlands (with a concentration of $2.5 \mathrm{mg} / 1 / 48$ hours $)^{[17]}$ then the water was totally replaced every 48 hours to maintain the activity of the hormone.

The fish were monitored in both the control and treatment group (summer and winter) to observe changes during the period of the experiment. A month later, the external appearance of both groups (males and females) was Figured. Then the width measurement of the thorax, abdomen, and caudal peduncle was then taken (Figure 1) as well as the total fish length (from the front of the body to the base of the fin) (Figure 2 and 3 ) in addition to measuring the length of the sword (from the tip of the fin to the end of the sword) in both the control group of the treatment group (summer and winter) (Figure 4) using digital caliper. 


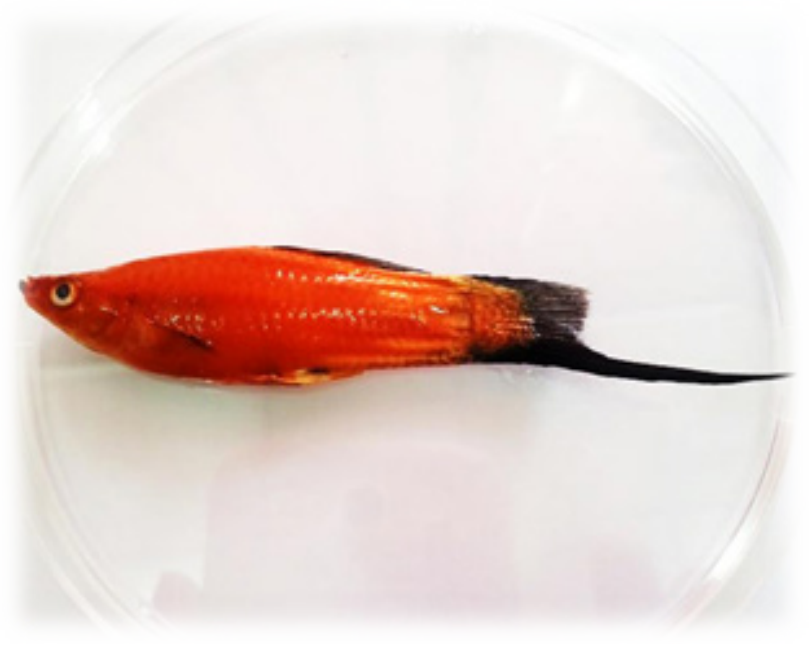

Fig. 1: An Fig. showing the areas of the body measured in the $\mathrm{X}$. helleri using digital caliper (A) thorax region, (B) abdomen region, (C) caudal peduncle, (D) sword.

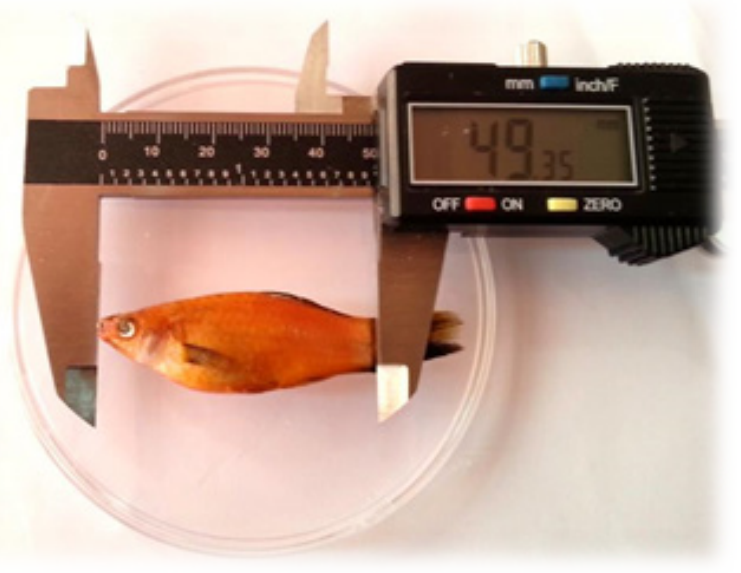

Fig. 2: An image showing the total body length of a female $X$. helleri using a digital caliper.

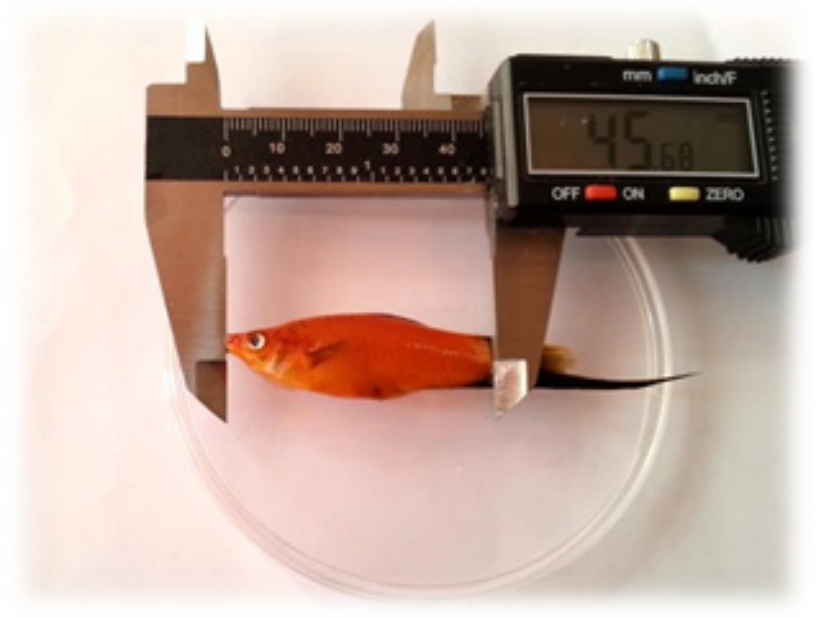

Fig. 3: An image showing the total body length of the male $X$. helleri using a digital caliper.

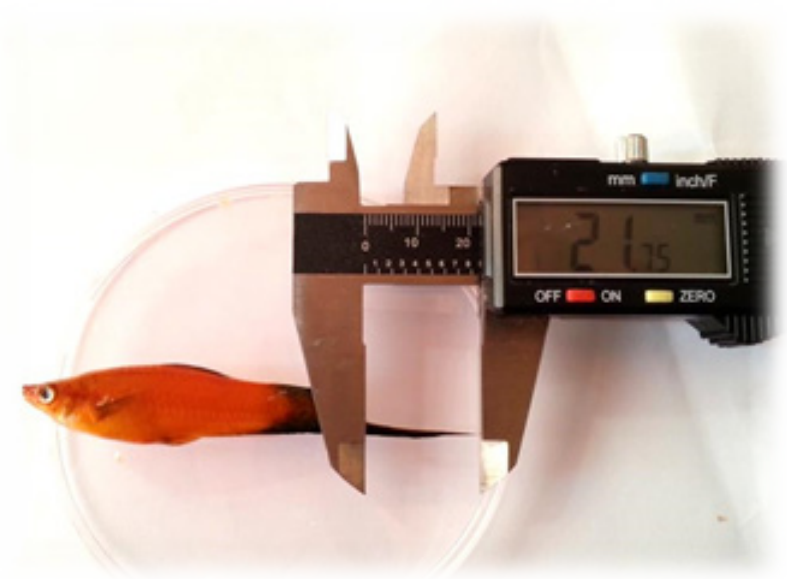

Fig. 4: An image illustrating the length of the sword of the male $\mathrm{X}$. helleri using a digital caliper.

The females of both groups (control and treatment) were then divided and their ovaries and eggs were also isolated. The numbers of embryos were calculated in each fish and were then examined under the anatomical microscope to follow up the phenotypic changes that occurred to distinguish the healthy embryos from the mutated or dead. The ovaries and embryos were then Figured under the Dissecting microscope and then kept with a formalin stabilizer $10 \%$.

\section{3 - Preparation of tissue sections}

The normal tissue sections of both ovaries and embryos were obtained using the Humason ${ }^{[18]}$ (1972) method, prior to the paraffin waxing, samples were washed with tap water for 12 hours to remove the fixer and then stored with an ethyl alcohol concentration of $70 \%$. The process was then carried out by passing samples with progressive concentrations of ethyl alcohol $80 \%$ and $90 \%$ for one hour each with the change and $100 \%$ for five hours with the change every hour. The samples were then emitted using the xylene for 10 minutes. The samples were then transferred to the melted paraffin wax in an electric oven $60 C^{\circ}$ for 5 hours with change per hour. The samples were then embedded in pure wax using special copper molds.

After cutting the wax blocks containing the samples, they were cut using Rotary microtome to cut the samples with a thickness of 7 micrometers and then transferred to the water bath with a temperature of $40-45 \mu \mathrm{m}$ to allow the sections to expand and flatten and then carried on clean glass slides. The sections were then pigmented with eosin and hematoxylin dual. The sections were then examined and Figured using the Leica composite imaging microscope.

\section{Statistical analysis}

All the data was analyzed by using statistical package the social (SPSS) statistics software for windows, version $17^{[19]}$. 


\section{RESULTS}

The results of the present study showed the effect of hydrocortisone and temperature on the phenotypic traits of $\mathrm{X}$. helleri, in addition to the impact of fish productivity during the period of the experiment.

\section{The effect of hydrocortisone and temperature on the external appearance of the female $X$. helleri}

\section{A - Experiment in Summer (ES)}

The results of the statistical analysis (Table 1) showed that there was no difference in the width of the thorax, abdomen, and caudal peduncle regions of the female $\mathrm{X}$. helleri treated with hydrocortisone and temperature $\left(28-34 \mathrm{C}^{\circ}\right)$ compared to control group females at the probability level $(P \leq 0.05)$. While the phenotypic changes focused on the fin of the treated fish, where there was a gradual elongation in the rays of the ventral part of the fin, which is the site of the sword in the male fish, after 18 days of treatment and represents the beginning of the emergence of the sword in the female fish. Early indications appear which are represented by the emergence of the sword as intensiveness in the Melanin pigment where a black line appears in the ventral portion of the caudal fin (Figures 5 and 6). Then the fin rays in this section gradually elongate with an increase in the Melanin pigment until the sword was clearly visible away from the edge of the rest of the parts caudal fin. After 30 days of treatment, there was an increase in the elongation of fin rays that vary in length depending on the fish (Figures 7-9) during the experimental period compared to the control group (Figure 5), where there was no change in the shape of the caudal fin. The elongation of the caudal fin was significant between the treated females and control group females at the probability level $(P \leq 0.05)$ (Table 1$)$.

\section{$B$ - Experiment in Winter $(E W)$}

The results of the statistical analysis (Table 1) of the winter experiment showed no change in the general external appearance, such as the width of thorax, Abdomen, and caudal peduncle regions in the females treated with hydrocortisone and temperature $\left(16-21 \mathrm{C}^{\circ}\right)$, compared to the females of the control group, except the caudal fin in which there was an elongation in the ventral region and the appearance of the sword. However, the elongation was very slow, compared to the females treated in the summer experiment, which was not significant at the probability level $(P \leq 0.05)$ (Table 2).

All the females of the experiment were in the initial stages of the sword formation, represented by the intensification of the Melanin pigment in the ventral part of the caudal fin, and then the elongation of that part, when completed a month of treatment (Figures 10-13). In the control group, on the other hand, there was no change in the shape of the fin during the period of the experiment.

\section{Effect of Hydrocortisone and Temperature on the ovaries and productivity of eggs}

The results of the microscopic examination of the female X. helleri ovaries in the control group for both experiments (summer and winter) showed that they were not affected by high $\left(28-34 \mathrm{C}^{\circ}\right)$ and low temperatures $\left(16-21 \mathrm{C}^{\circ}\right)$. Some ovaries appeared to be composed of a group of roughly equal eggs with yellow-colored lumps, some contain embryos in different developmental stages and some did not have such embryos (Figure 14). While all other ovarian eggs contained embryos of different ages. The number of embryos was between (40-60), but the ovaries of the treatment group had a set of changes that can be clarified as follows:

\section{A - Experimental Summer (ES)}

The results of the microscopic examination of the female $\mathrm{X}$. helleri ovaries treated with Hydrocortisone and temperature $\left(28-34 \mathrm{C}^{\circ}\right)$ showed three developmental conditions of the ovary in the female fish of this experiment. The first case was an undeveloped ovary (eggs do not contain embryos) that was small in size compared to the other ovaries of the same experiment. It contained large numbers of small white eggs, with orange granules scattered among ovarian eggs (Figure 15). In the second case, the ovaries were large in size. The eggs were decayed whose limits were unclear with pale yellow yolks and there were 1-2 dead and semi-decayed embryos. The embryos appeared to be combined with the adjacent eggs (Figure 16). In the third case, the size of the ovary was similar to the one in the second case and the eggs had clear-cut limits and yellow yolks. Most of these eggs contained clear embryos of different ages. However, all embryos were dead (Figure 17). The number of embryos was (1-9).

\section{B - Experimental Winter $(E W)$}

The results of the microscopic examination showed that most female $\mathrm{X}$. helleri treated with Hydrocortisone and temperature $\left(16-21 \mathrm{C}^{\circ}\right)$ contained large numbers of embryos compared to the experiment in summer, with a rate of (3-33) embryo. Embryos appeared to be of different development stages, but the majority o were dead, surrounded by bloody clots (Figure 18), while some of the ovaries were undeveloped (not containing embryos), containing a number of white eggs with some blood clots and some were in atrophy (Figures 19 and 20).

It was noticed through the histological examination of the ovaries of the treatment group that there were clear changes that included some development phases of the eggs compared to the ovaries of the control group. These changes appear in both the fourth (IV) and the fifth (V) development phases of the eggs. Some egg cells in the development stage (IV) showed swelling in the epithelial cells of the ovarian cell wall and the decay of part of it 
as well as the decay of the cytoplasm and the extension of a hole within the large nucleus (Figure 22). It was also noticed that there was decay in the nucleus and the emergence of its remainders in the form of a circle inside the nuclear (Figure 23) compared to the control group (Figure 21).

As for the fifth (V) development phase of the eggs in the ovaries of the treatment group, it showed a deformity of the exterior of the ovary cell and its loss of the spherical shape with the lysis of parts of the cytoplasm (Figures 24 and 25). In another case, the cytoplasm was condensed and observed outside the wall surrounding the cell (Figure 26), in addition to the lysis of some of the cells of this phase (Figure 27) compared to the control group (Figure 24).

There were several types of phenotypic deformed in the embryos. These deformed were concentrated on the head and trunk area. Some of the embryos had swelling in the back region of the head (Figure 28). It was noticed that there was a torsion appeared in different locations of the spine which led the trunk not to be of one straightness. The torsion may occur in the posterior third of the spine near the caudal fin, making the embryo's body of an S-shape
(Figure 29) or may occur in the middle part of the spine so the embryo's body become of L-shape (Figure 30). Some of the other embryos showed deformed in both the head and trunk areas, where head elongation was found with a sharp curvature in the front of the spine near the head, making the trunk extend parallel to the head covering the whole yolk (Figure 31).

The results of the histological examination showed that there was a deformity of the cartilage in the cerebral cortex at the level of the frontal brain, where a hole was observed (Figure 32) compared to the control group (Figure 33). The cartilage hyperplasia was observed in this region, and the cartilage appears thick (Figure 34) in comparison to the rest of the other cartilage parts compared to the control group (Figure 35). Hyperplasia was also observed in the brain cells of the frontal cortex in the area corresponding to the hole in the brain walls and its movement through the hole towards the skin (Figure 36).

The percentage of the total number of embryos (the healthy, deformed and dead) in both the control and treated groups (summer and winter experiment) can be explained in the following (Table 3)

Table 1: Measurements of different body regions of X. helleri (control males (Con.M), control females (Con. F), female summer treatment (Tre.F.S), female winter treatment (Tre.F.W)), adjusted \pm standard error, $\mathrm{n}=3$, significant (Sig ).

\begin{tabular}{|c|c|c|c|c|c|c|c|c|}
\hline Sex & Total lengh & Sig & Chest width & Sig & $\begin{array}{l}\text { Abdomen } \\
\text { width }\end{array}$ & Sig & caudal peduncle & Sig \\
\hline Con. M & $46.96 \pm 0.63$ & \multirow{2}{*}{1.00} & $11.89 \pm 0.80$ & \multirow{2}{*}{1.00} & $14.29 \pm 0.21$ & \multirow{2}{*}{1.00} & $9.82 \pm 0.49$ & \multirow{2}{*}{0.52} \\
\hline Con. F & $44.36 \pm 2.66$ & & $11.85 \pm 1.35$ & & $15.23 \pm 1.30$ & & $8.51 \pm 0.44$ & \\
\hline Con. F & $44.36 \pm 2.66$ & \multirow{2}{*}{1.00} & $11.85 \pm 1.35$ & \multirow{2}{*}{1.00} & $15.23 \pm 1.30$ & \multirow{2}{*}{1.00} & $8.51 \pm 0.44$ & \multirow{2}{*}{1.00} \\
\hline Tre. F.S & $41.20 \pm 0.93$ & & $11.37 \pm 0.56$ & & $13.91 \pm 1.09$ & & $7.82 \pm 0.53$ & \\
\hline Con. F & $44.36 \pm 2.66$ & \multirow{2}{*}{1.00} & $11.85 \pm 1.35$ & \multirow{2}{*}{1.00} & $15.23 \pm 1.30$ & \multirow{2}{*}{1.00} & $8.51 \pm 0.44$ & \multirow{2}{*}{1.00} \\
\hline Tre. F.W & $41.40 \pm 1.06$ & & $12.55 \pm 0.39$ & & $16.20 \pm 0.68$ & & $8.63 \pm 0.42$ & \\
\hline Tre. F.S & $41.20 \pm 0.93$ & \multirow{2}{*}{1.00} & $11.37 \pm 0.56$ & \multirow{2}{*}{1.00} & $13.91 \pm 1.09$ & \multirow{2}{*}{0.70} & $7.82 \pm 0.53$ & \multirow{2}{*}{1.00} \\
\hline Tre. F.W & $41.40 \pm 1.06$ & & $12.55 \pm 0.39$ & & $16.20 \pm 0.68$ & & $8.63 \pm 0.42$ & \\
\hline
\end{tabular}

Table 2: Measurement of sword length of $X$. helleri (control males, control females, female summer treatment, female winter treatment), adjusted \pm standard error, $\mathrm{n}=3{ }^{*}$ significant (Sig ) at the level $P \leq 0.05$.

\begin{tabular}{|c|c|c|}
\hline Sex & sword length & Sig \\
\hline control males & $20.30 \pm 2.62$ & \multirow{2}{*}{$0.002^{*}$} \\
\hline female summer treatment & $6.08 \pm 0.03$ & \\
\hline control females & $0.00 \pm 0.00$ & \multirow{2}{*}{$0.000^{*}$} \\
\hline female summer treatment & $6.08 \pm 0.03$ & \\
\hline control males & $20.30 \pm 2.62$ & \multirow{2}{*}{$0.000^{*}$} \\
\hline female winter treatment & $1.52 \pm 0.83$ & \\
\hline control females & $0.00 \pm 0.00$ & \multirow{2}{*}{$0.000^{*}$} \\
\hline female winter treatment & $1.52 \pm 0.83$ & \\
\hline female summer treatment & $6.08 \pm 0.03$ & \multirow{2}{*}{0.234} \\
\hline female winter treatment & $1.52 \pm 0.83$ & \\
\hline
\end{tabular}


Table 3: The average of embryos and the percentage of healthy, deformed and dead embryos in both control and treated groups with Hydrocortisone and temperature.

\begin{tabular}{lccc}
\hline & $\begin{array}{c}\text { Control group } \\
\text { with out hormone/(25-28) C }\end{array}$ & $\begin{array}{c}\text { Tretment group } \\
\text { Hydrocortison/(16-21) } \mathrm{C}^{\mathrm{o}}\end{array}$ & $\begin{array}{c}\text { Tretment group Hydrocortison/ } \\
(28-34) \mathrm{C}^{\mathrm{o}}\end{array}$ \\
\hline average of embryos number & 50 embryo & 17 embryo & 4 embryo \\
percentage of embryos dead & $0 \%$ & $60 \%$ & $100 \%$ \\
percentage of embryos deformed & $0 \%$ & $30 \%$ & $0 \%$ \\
percentage of embryos healthy & $100 \%$ & $10 \%$ & $0 \%$ \\
\hline
\end{tabular}

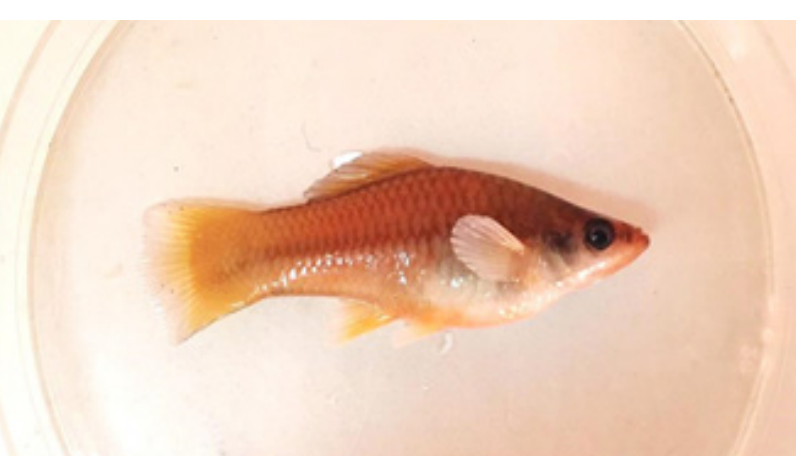

Fig. 5: Female control X. helleri, notice the caudal fin (arch).

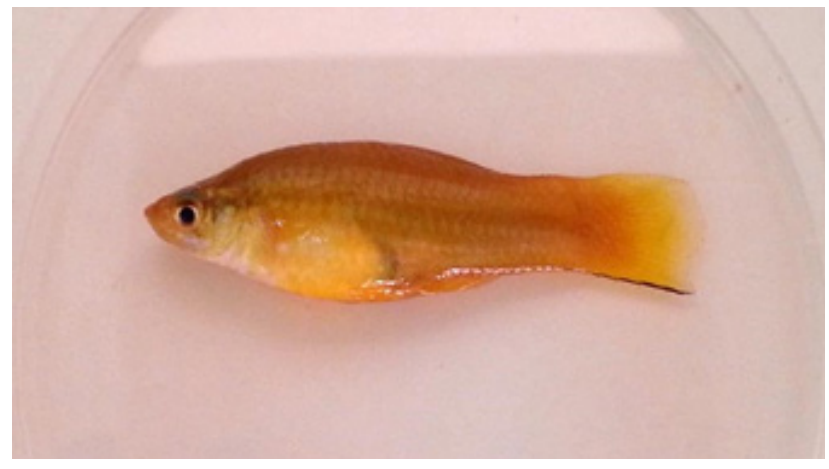

Fig. 6: Female X. helleri (ES) treated for 18 days, showing the beginning of condensed melanin (arrows) in the form of a thin black line in the ventral part of the caudal fin (arch), pointing to the beginning of the elongation of the fin rays ( from which the sword emerges) in the site of sword formation.

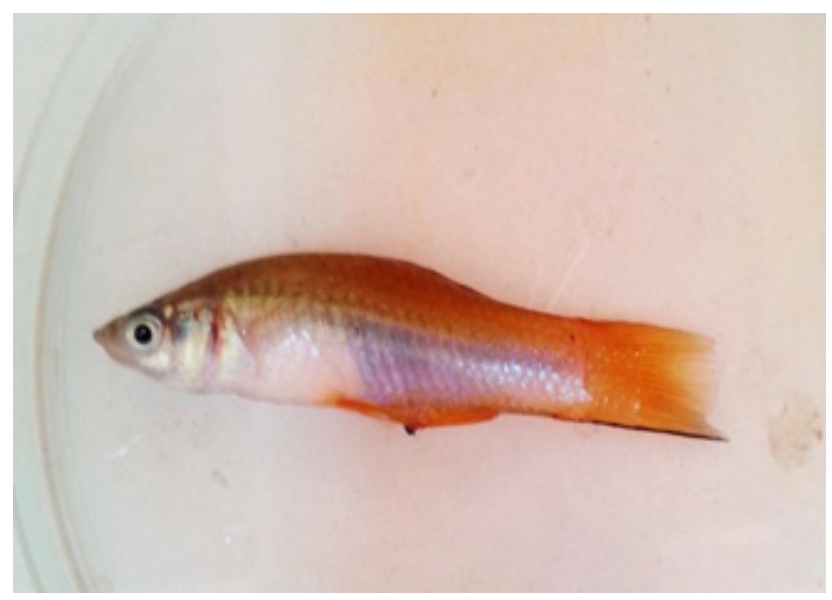

Fig. 7: Female X. helleri (ES) treated for 30 days, observe the emergence of fin rays, which is the beginning of the sword formation (arrow) slightly above the level of the caudal fin(arch).

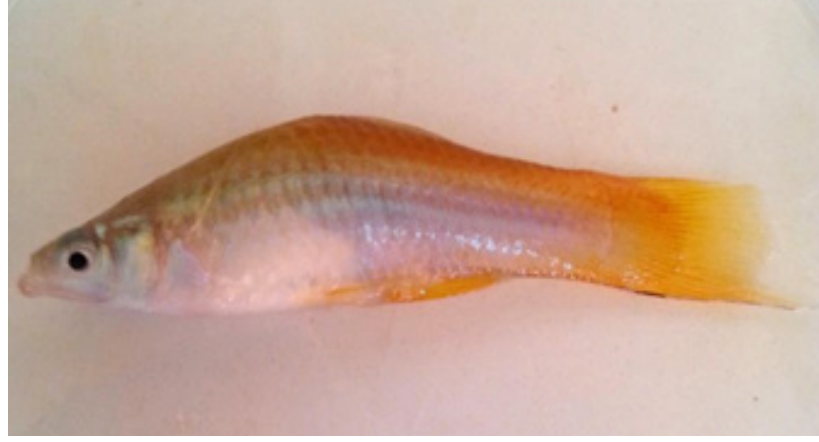

Fig. 8: Female X. helleri (ES) treated for 30 days, notice the apparent increase in elongation of fin rays (arrows) (equities) from the level of the caudal fin (arch).

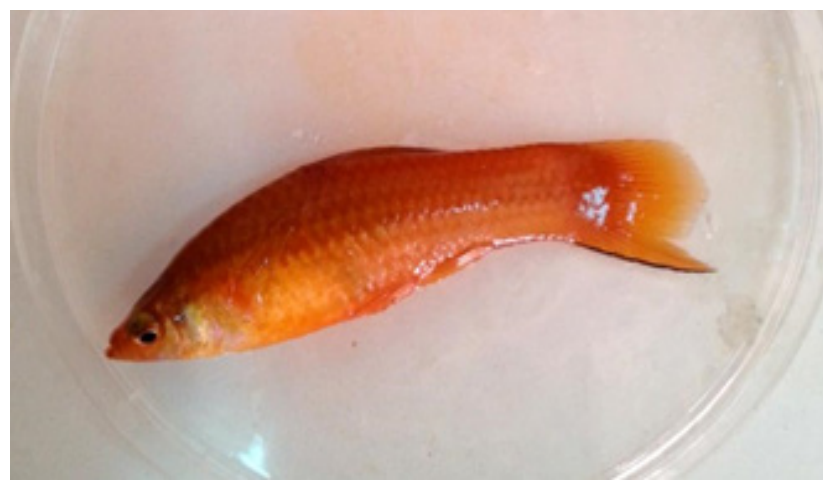

Fig. 9: Female $X$. helleri (ES), treated for 30 days, the sword appears clearly (arrows) on the level of the caudal fin (arch).

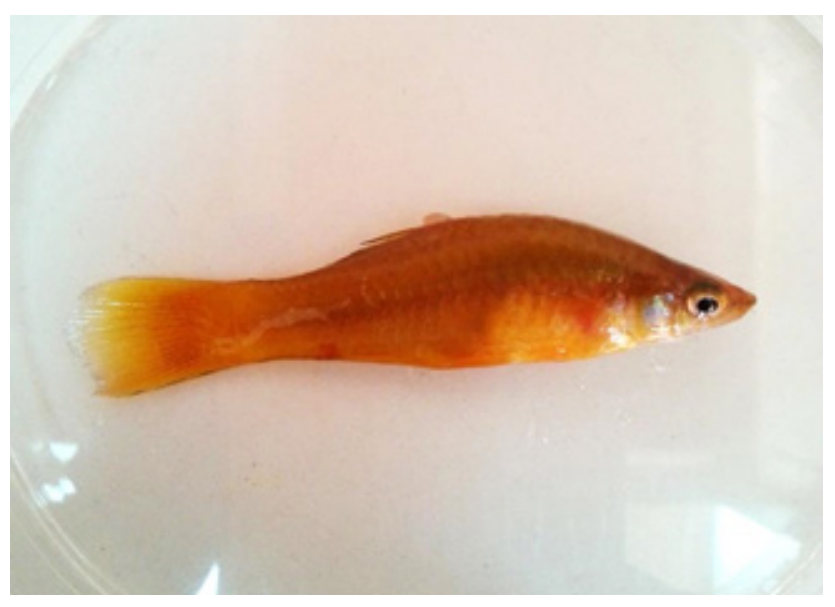

Fig. 10: Female X. helleri (EW) treated for 30 days. Notice that the melanin pigment appears in the form of non-continuous masses (arrows) like in a small, black line in the ventral part of the caudal fin(arch). 


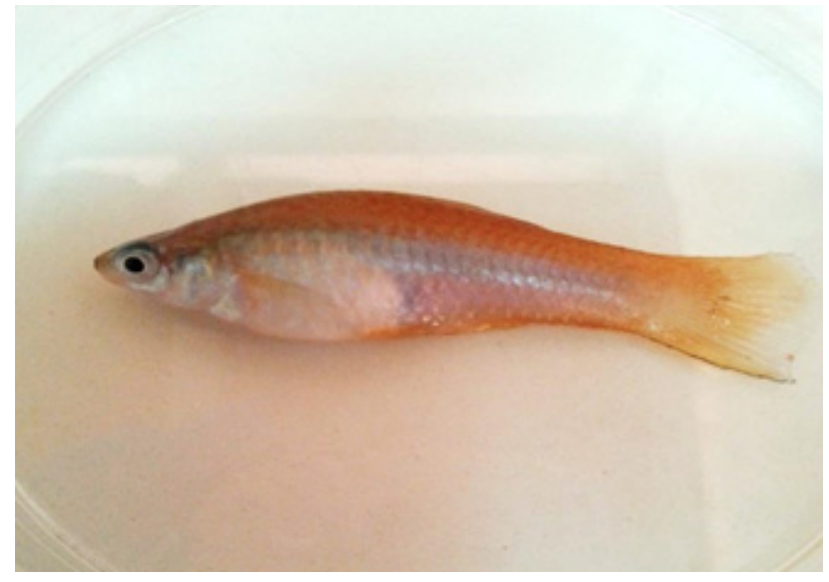

Fig. 11: Female X. helleri (EW) treated for 30 days, see the melanin pigment intensification (arrows) in a fine black line in the ventral part of the caudal fin (arch) (arrow).

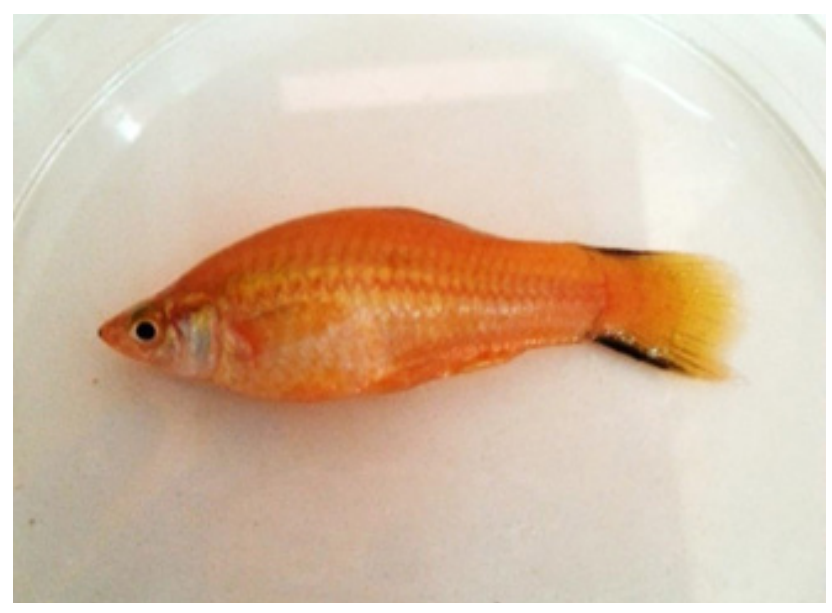

Fig. 12: Female $X$. helleri (EW) treated for 30 days, notice the emergence of the sword (arrow) slightly above the level of the caudal fin (arch).

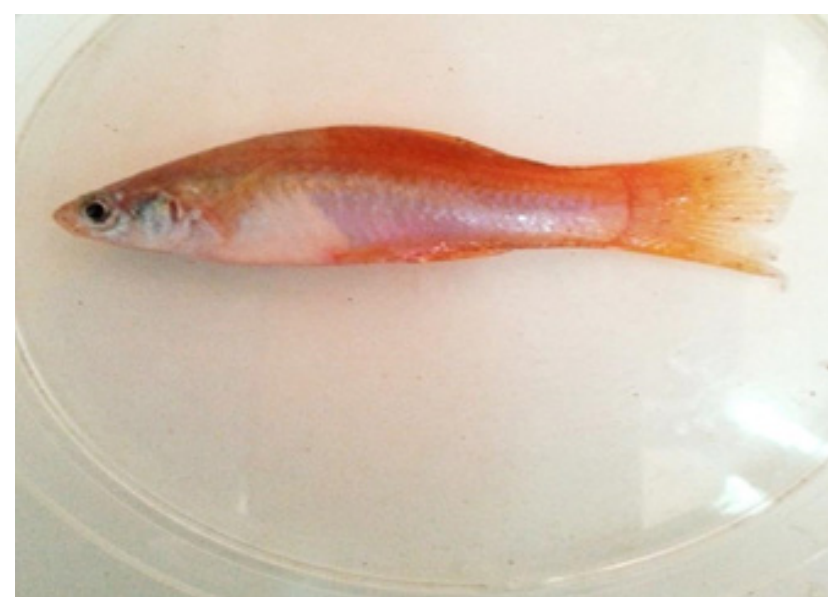

Fig. 13: Female $X$. helleri (EW) treated for 30 days, notice the emergence of the sword (arrow) slightly above the level of the caudal fin (arch).

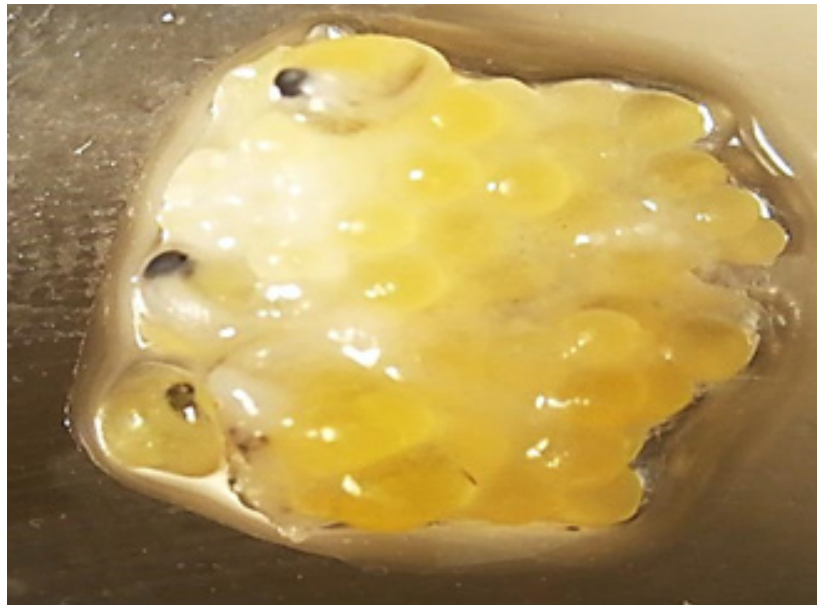

Fig. 14: Ovary of female $X$. helleri control, notice embryos (arrows) and eggs (stars) 160x.

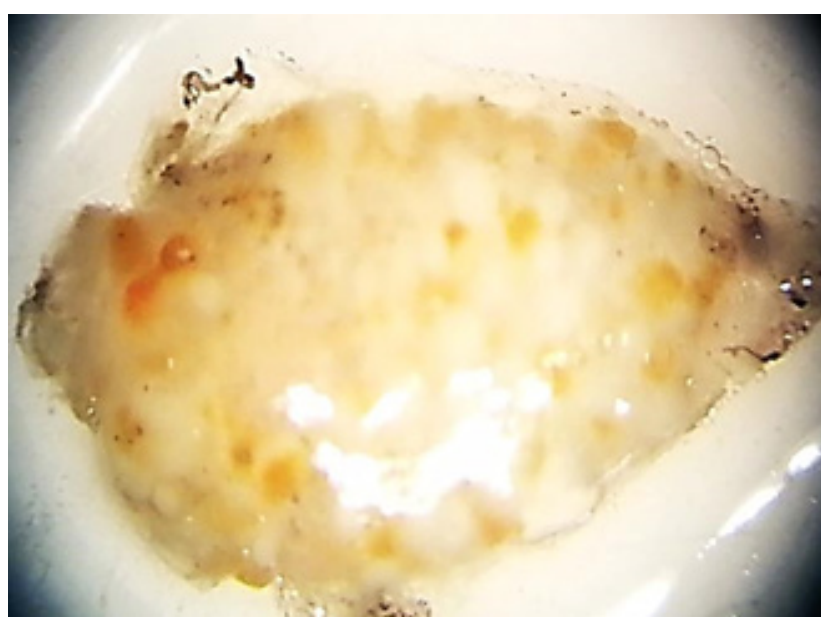

Fig. 15: Ovary of female X. helleri experimental summer (ES), showing the first case of undeveloped ovaries, see the orange grains (arrows) 160x.

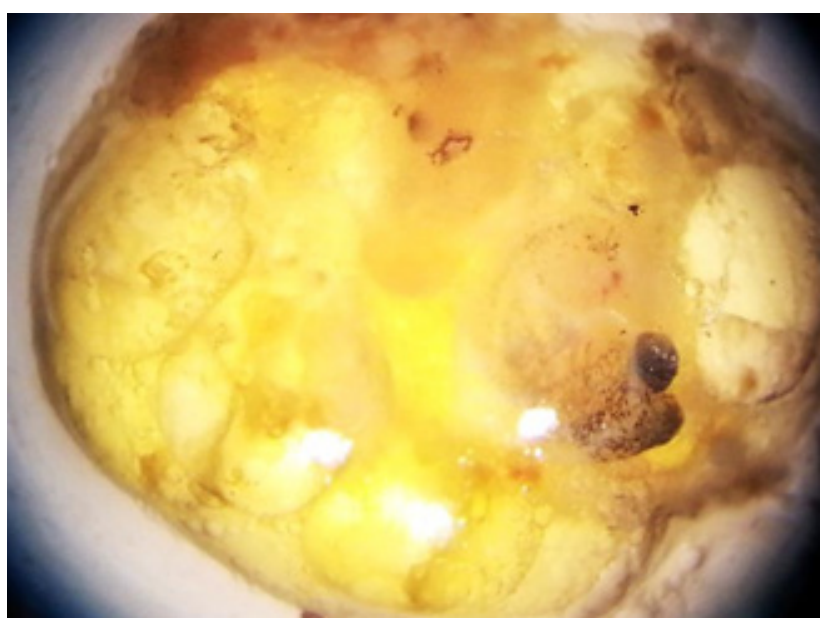

Fig. 16: Ovary of female X. helleri experimental summer (ES) showing the second case of the ovary, notice the semi-decayed embryo (circle), the decayed eggs (stars), 160x. 


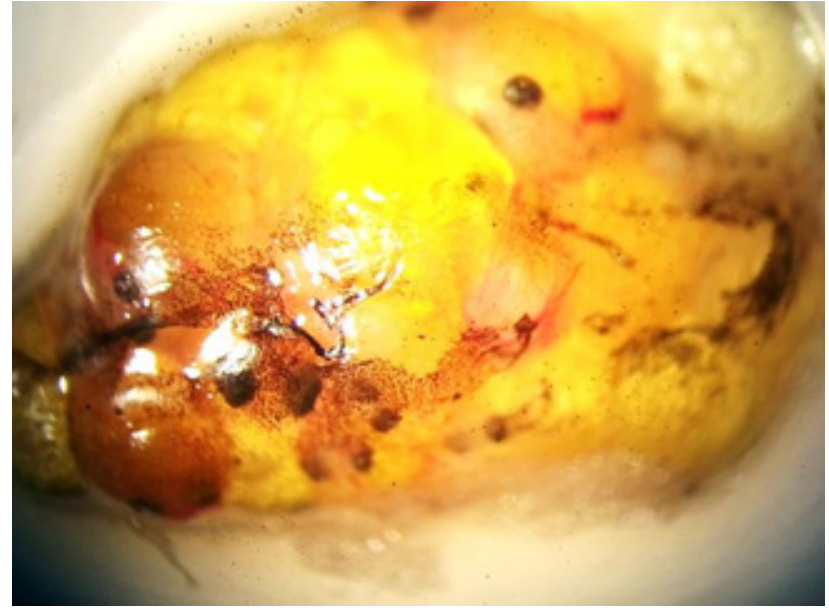

Fig. 17: Ovary of female X. helleri experimental summer (ES), showing the third state of the ovaries, notice the numbers of dead embryos (arrows) 160x.

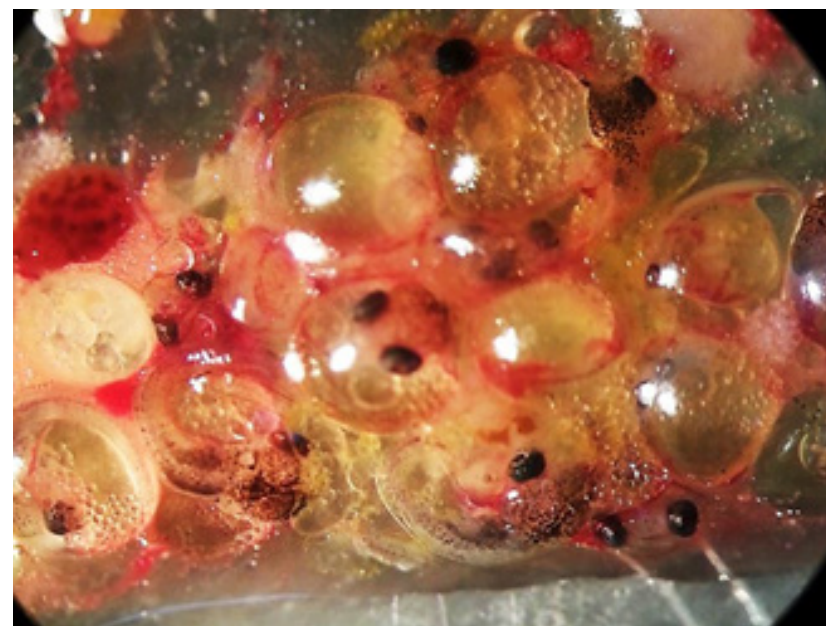

Fig. 18: Ovary of female X. helleri experimental winter (EW), showing embryos at different ages, notice the blood clots (arrows), 160x.

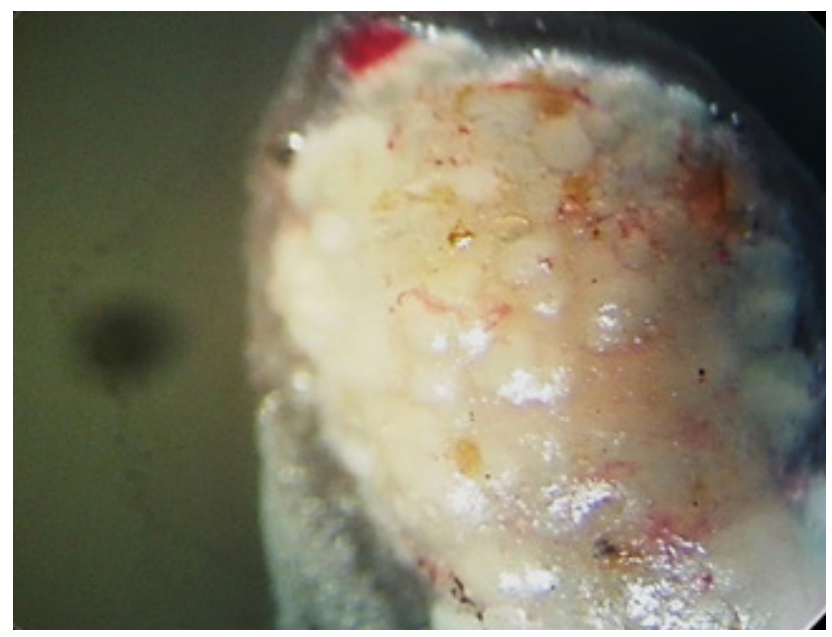

Fig. 19: Ovary of female $X$. helleri experimental winter (EW), illustrating the underdeveloped ovary, observe the blood clot (arrow), 160x

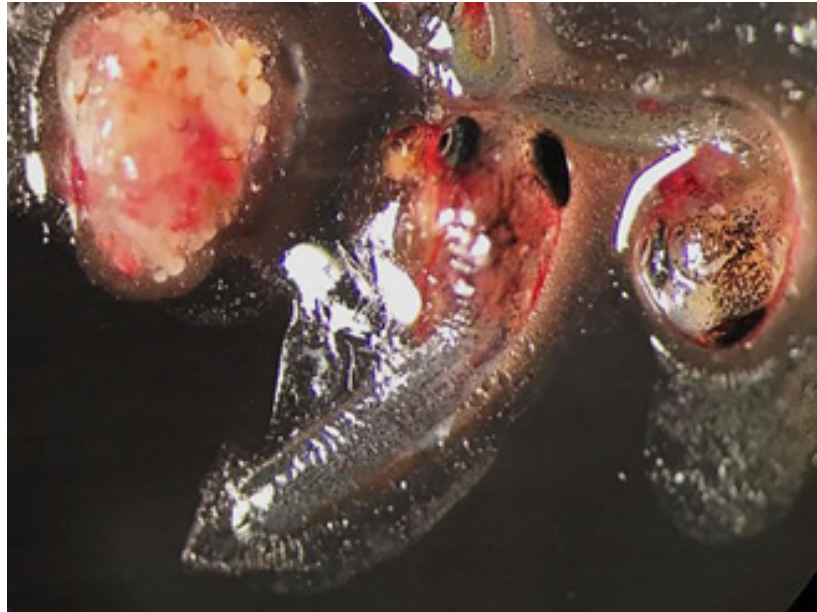

Fig. 20: Ovary of female $X$. helleri experimental winter (EW), indicating ovarian atrophy (OV), observe the blood clot (arrow), embryo (EM), 160x.

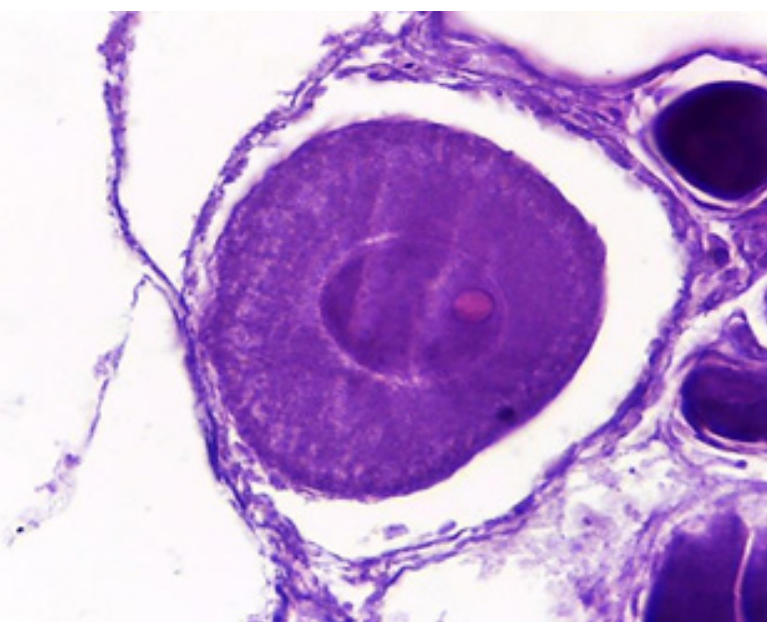

Fig. 21: Egg cell (the stage IV) of the ovary of the control group, notice the spherical nucleus (arrow), nuclear $(\mathrm{N})$, cytoplasm $(\mathrm{C})$, $\mathrm{H} \& \mathrm{E}, 400 \mathrm{x}$

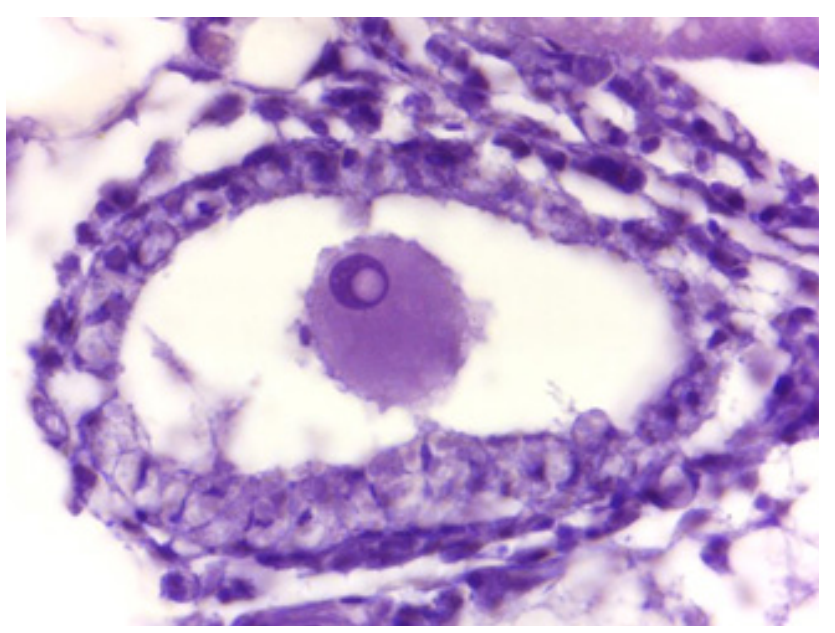

Fig. 22: Shows the swelling of the epithelial cells of the egg cell wall (stage IV wall) (large arrows) of the ovary of the treatment group. Notice that part of the wall is lysised (star) and apper of a hole within the nuclear (small arrow) H\&E, 1000x. 


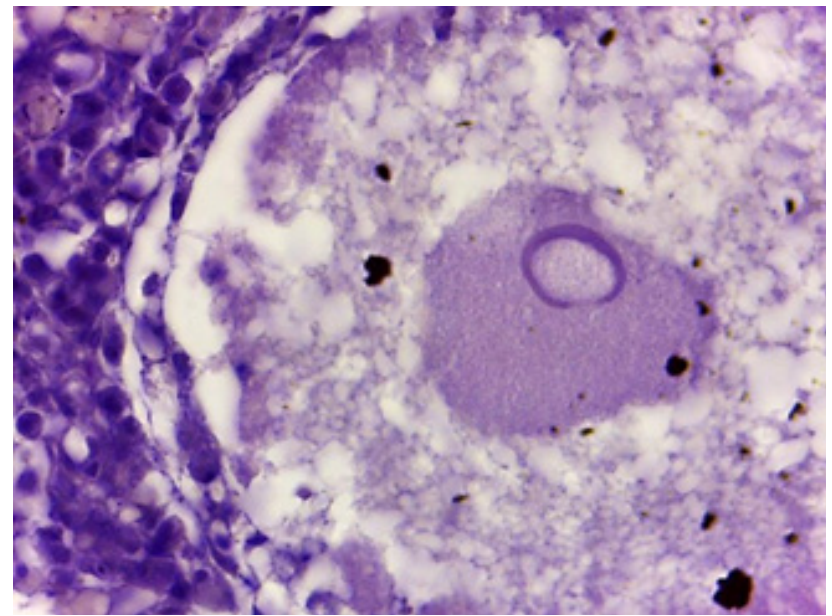

Fig. 23: The lysis of the nucleus and its appearance in the form of a circle (arrow) within the irregular nuclear cell (stage IV) of the ovary of the treatment group, nuclear $(\mathrm{N}), \mathrm{H} \& \mathrm{E}, 1000 \mathrm{x}$.

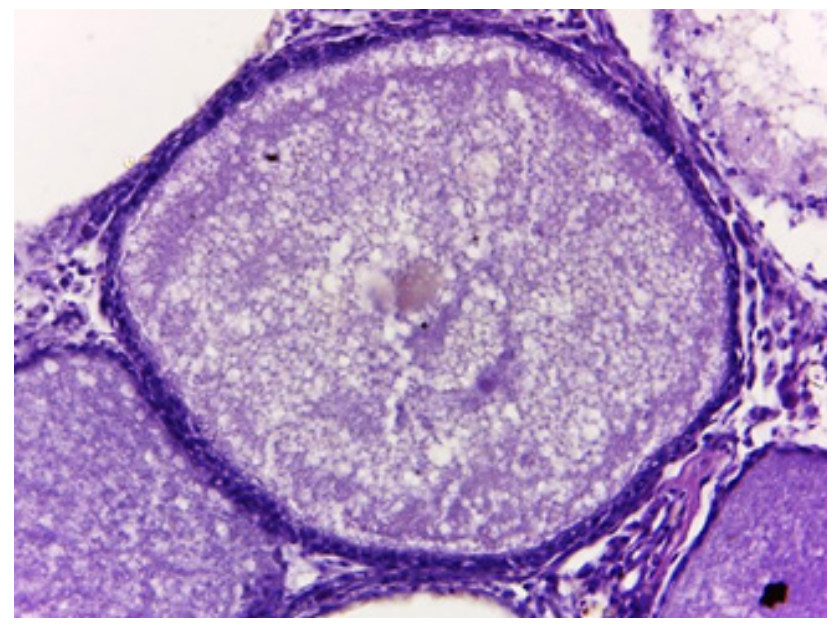

Fig. 24: Clarifies the egg cell (stage V) of the ovary of the control group with regular circular shape H\& E, 400x.

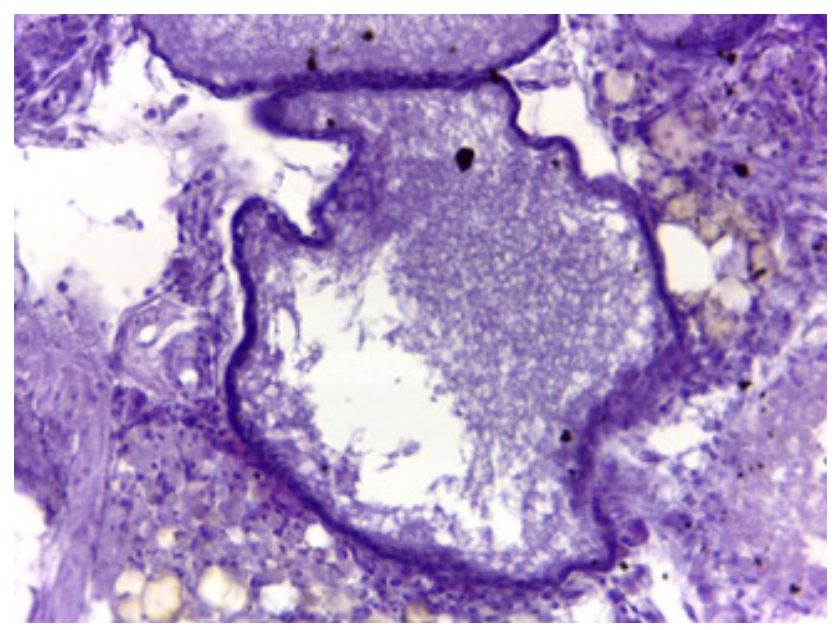

Fig. 25: The egg cell (stage V) of the ovary of the treatment group, observe the irregular exterior shape and lysis of part of the cytoplasm (arrows), H\& E, 400x.

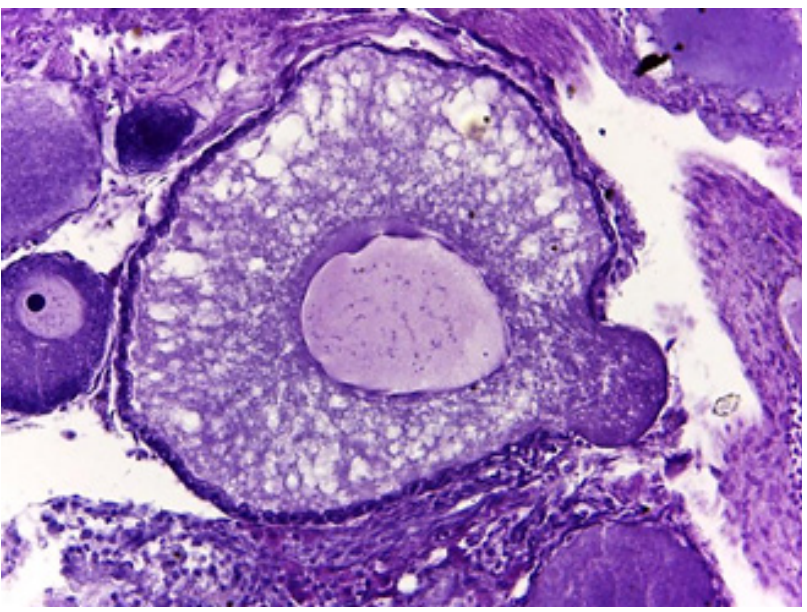

Fig. 26: The egg cell (stage V) of the ovary of the treatment group, observe the cytoplasm's migration by penetrating the cel exterior and condensing of the cytoplasm (arrows), H\& E, 400x.

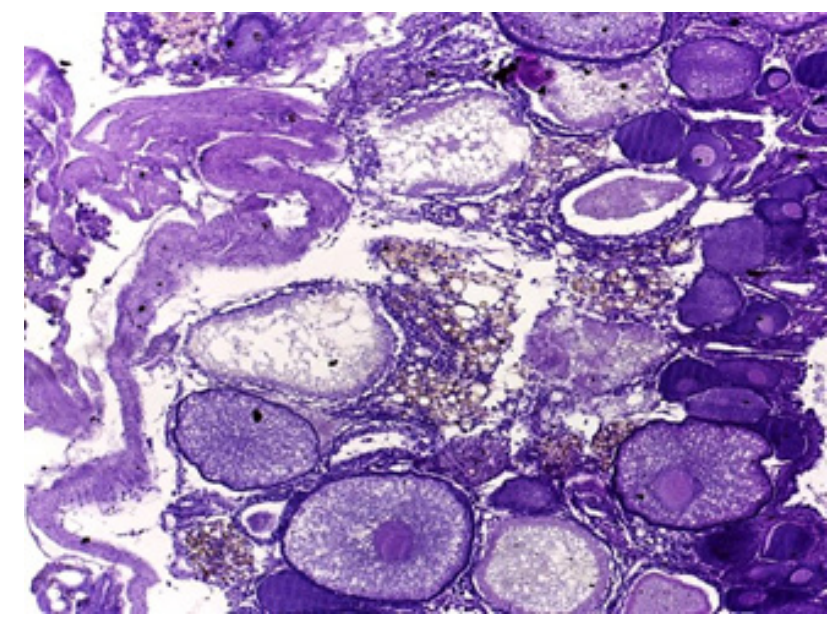

Fig. 27: Clarifies the decay of a group of egg cells (stage V) of the ovary of the treatment group (stars), H\& E, 100x.

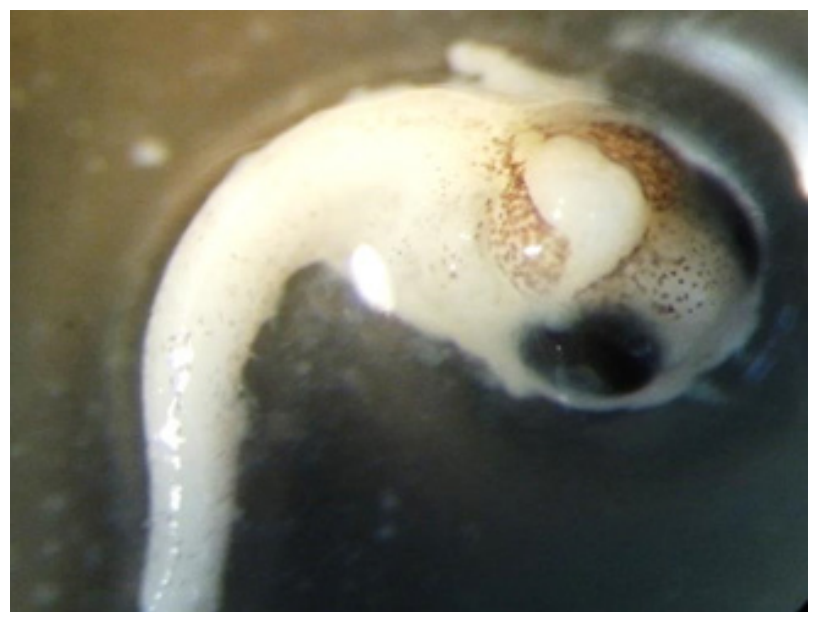

Fig. 28: Shows deformity in the head of the embryo. Notice that swelling occurs in the back region of the head (arrows), head $(\mathrm{H})$, trunk (T), (winter experiment), 160x. 


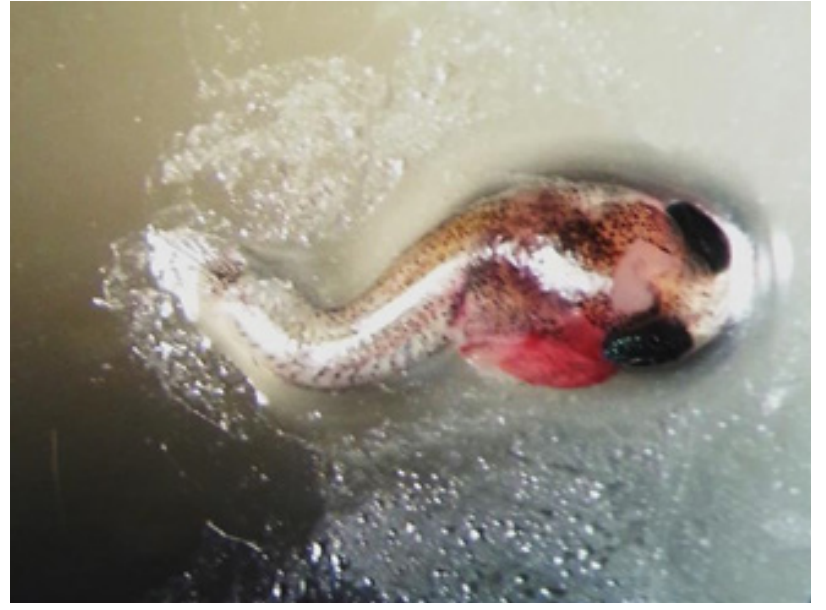

Fig. 29: Shows the torsion in the posterior third of the spine (bow). Notice that there is swelling in the dorsal roof of the head (arrows), head (H), trunk (T), (winter experiment), 160x.

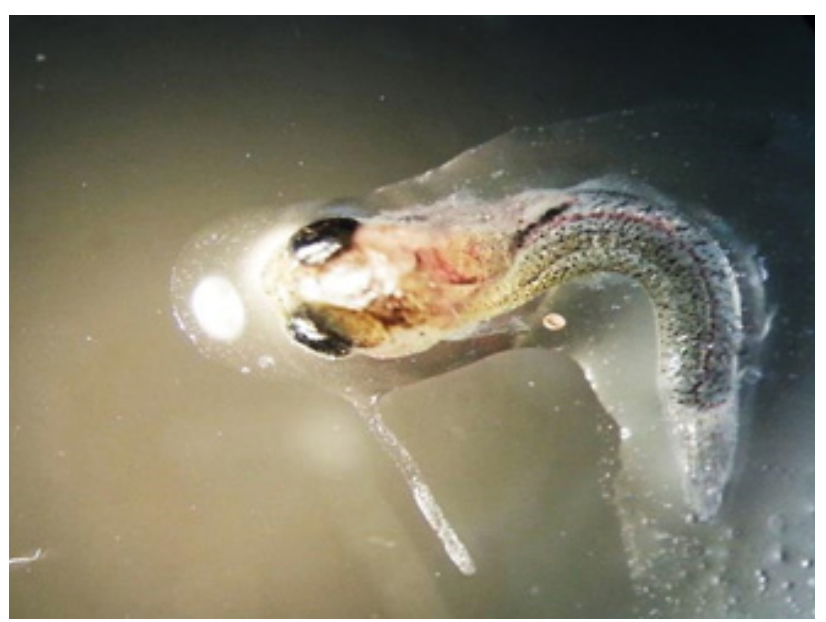

Fig. 30: The torsion in the middle part of the embryo's spine (bow), head $(\mathrm{H})$, trunk $(\mathrm{T})$, (winter experiment), 160x.

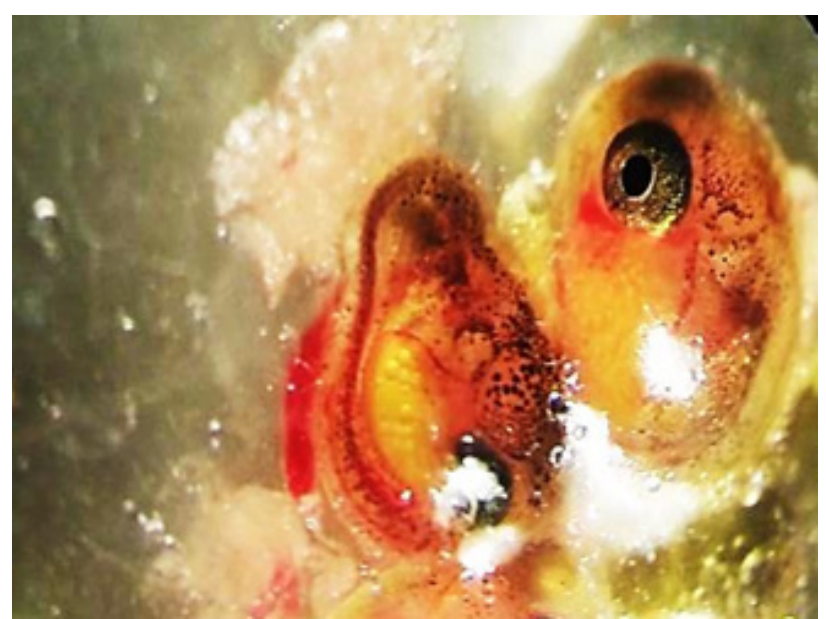

Fig. 31: Shows a curvature at the front of the spine near the head (bow). Notice the trunk parallel to the head covering of the yolk, the head $(\mathrm{H})$, the yolk (Yo), (winter experiment), 160x.

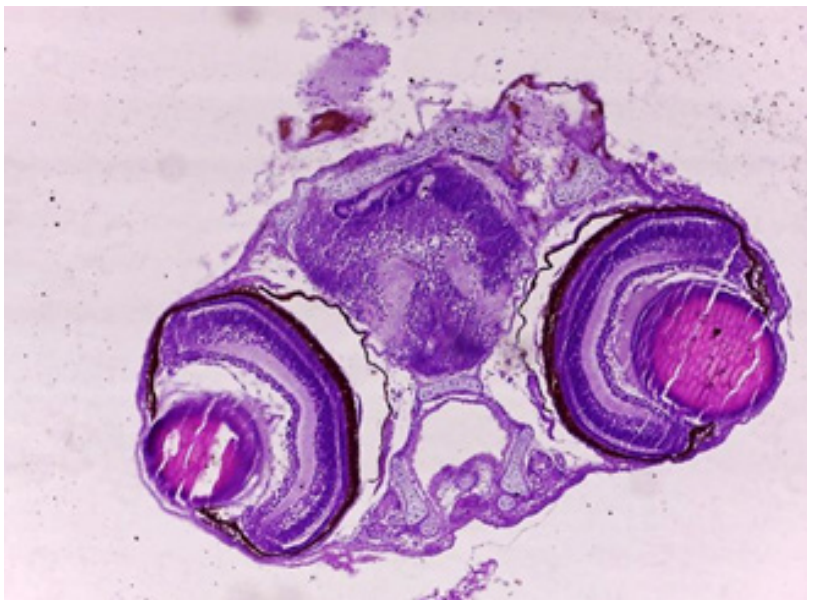

Fig. 32: Shows a hole(arrows) in the forebrain $(A B)$ of the embryo length $4 \mathrm{~mm}$, treated, (winter experiment), $\mathrm{H} \& \mathrm{E}, 100 \mathrm{x}$.

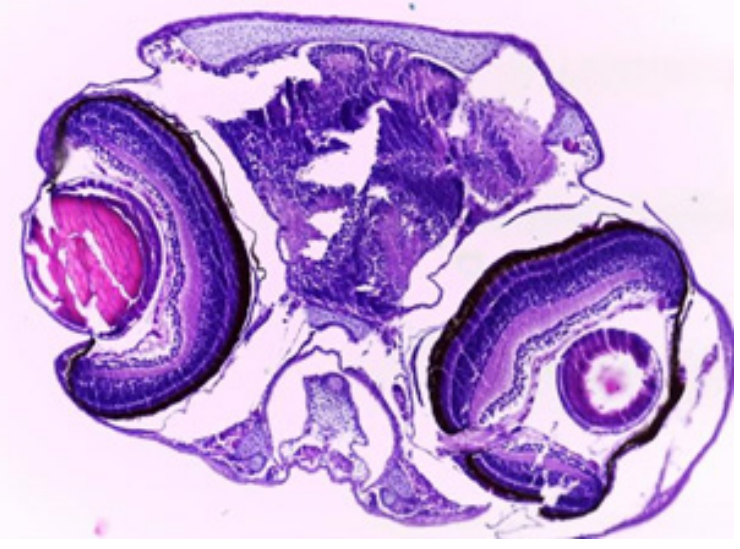

Fig. 33: Shows the frontal(arrows) cartilage (AB) of the embryo length $4 \mathrm{~mm}$, control, (winter experiment), H\& E, 100x.

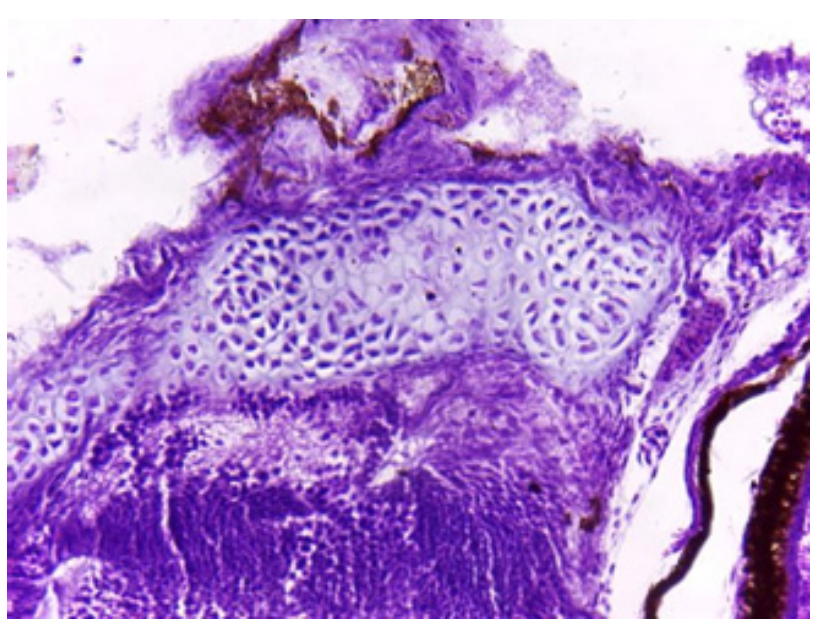

Fig. 34: The cartilage hyperplasia (arrows) in the frontal cartilage (AB) of the embryo length $4 \mathrm{~mm}$ (winter experiment), $\mathrm{H} \& \mathrm{E}$, $400 x$ 


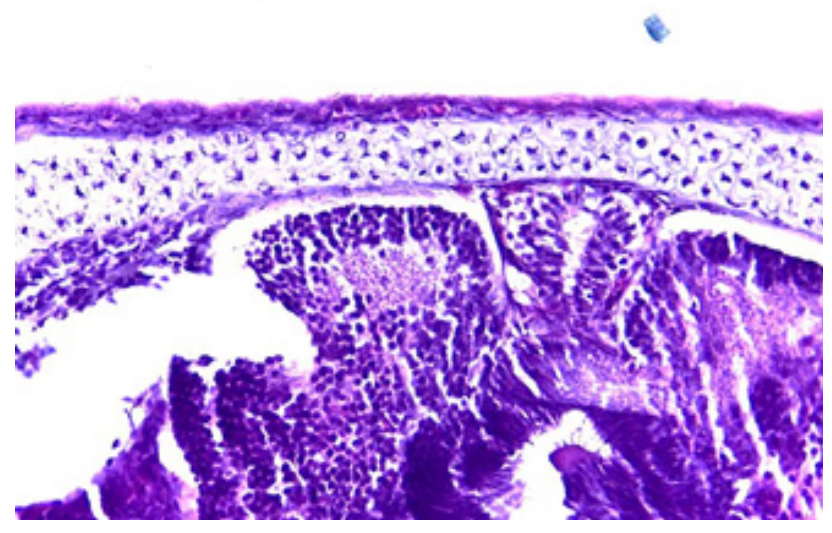

Fig. 35: Shows the cartilage(arrows) of the forebrain $(A B)$ of the embryo length $4 \mathrm{~mm}$, control (winter experiment), H \& E, 400x.

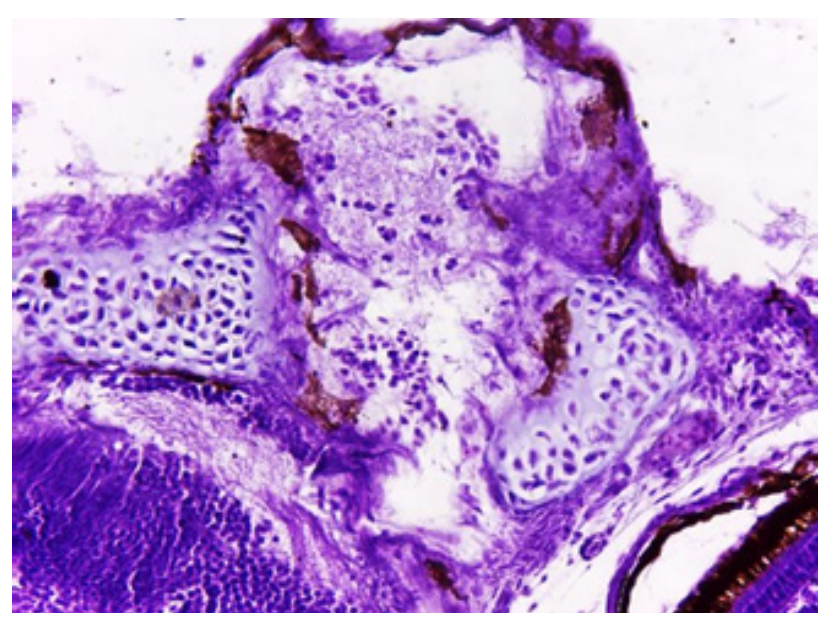

Fig. 36: Neuronal hyperplasia of the cerebellar cortex (small arrows) and their movement through the hole toward the skin (large arrows) of a 4-mm embryo, treated, H\& E, 400x.

\section{DISCUSSION}

Sexual transformation is a common phenomenon in fish in general as it has been observed in many species, such as goby and zebrafish and other kinds especially X. helleri. This phenomenon results in a change in sexual characteristics, whether initial sexual characteristics represented in gonadal sex or secondary such as body shape and pigments found on the body of the fish ${ }^{[20]}$

Sexual transformation in fish occurs during different age stages. It may occur during the early stages of the larvae and young phase ${ }^{[6]}$ or may occur in mature fish. It has been found in much marine fish in response to environmental changes ${ }^{[21]}$. This is observed in the present study, with the phenomenon of sexual transformation occurring in the mature females of X. helleri.

The results of the current study showed that sexual transformation in the female X. helleri was only in terms of appearance by increasing the length of the ventral rays of the caudal fin with an increase in the Melanin pigment, giving it an appearance similar to the sword in the males (this is regarded as the most important distinction between males and females in this species).
The current study did not found any sexual change in the female genitals (ovaries) of X. helleri as females still had the ovaries, although they may have been apparently transformed into males. This may be due to the age at which sexual transformation occurred. It may not be possible to change the gonads in adult fish because of the completion of sexual maturity compared to the early stages in which the gonads are still immature, which makes them capable of changing their sexual status ${ }^{[16]}$. In fish whose genitalia are still in their early stages, the sexual transformation has been observed. Both male and female sex cells have been observed to be present together. As a result of age, the final sex is determined to depend on the conditions in which the fish lives. This is observed in the Zebrafish, as the male reproductive gonads have primary oocytes. If these cells are decayed by programmed apoptosis, the females will become males, but if the primary ovarian cells are preserved, the gonads will differentiate into the ovaries and become young females ${ }^{[20]}$.

Both temperature and cortical hormones play a significant role in the process of sexual transformation in fish, as observed in the females of X. helleri treated with hydrocortisone and heat, as both high and low temperatures and cortical hormones stimulate the phenomenon of sexual transformation of mature females into males.

The current study has proved that the process of sexual transformation occurs more rapidly on fish treated in high temperature and Hydrocortisone, compared to fish treated under low temperature and Hydrocortisone. The appearance of male phenotypes, namely elongation in the ventral rays of the caudal fin began in the $\mathrm{X}$. helleri treated at $\left(28-34 \mathrm{C}^{\circ}\right)$ and hormone after 18 days of treatment, while male phenotypic traits began to appear on females treated at $\left(16-21 \mathrm{C}^{\circ}\right)$ and the hormone at the end of the treatment period, probably because high temperatures increase the exhaustion of fish, leading to increased secretion of cortical hormones, which in turn affect the levels of androgen hormone in fish plasma ${ }^{[22,23]}$. It was found that the increase in levels of the androgen is due to increased levels of cortisol, which in turn regulates the production of the androgen in the body by directly inhibiting the genetic expression of the gene cyp 19ala responsible for the production of aromatase necessary in the conversion of androgen to estrogen in females to maintain ovarian functions ${ }^{[24,25]}$. Thus, increasing the level of androgen resulting from increased levels of cortical and the lack of estrogen inhibits the development of the ovary, including its cells, whether sexual or body responsible for secondary female sexual characteristics, while thermally induced, which leads to a state of masculinity ${ }^{[26,27]}$.

The results of the current study indicate that temperature play the main role in sexual transformation compared to Hydrocortisone, which emerged as a catalyst in this process, as the process of sexual transformation occurred in both summer and winter experiments, but the hydrocortisone stimulated this process in the summer experiment more than the winter experiment, and this proves what recent 
studies have suggested by regarding cortisol as a key factor that links the stimulation of external environmental factors to the internal physiological response during sexual development ${ }^{[28,29]}$.

There may be other factors that play a role in stimulating sexual transformation. Among these factors is the ratio of males to females, as indicated by Dranow et al. ${ }^{[20]}$, who mentioned that the presence of one male in a female squadron in goby fish urges sexual transformation, but in the current study the percentage of males is $40 \%$, which means that the percentage of males have no effect in the induction of this phenomenon or perhaps there could be a role for males depending on the type of fish.

Corticosteroids generally affect the reproductive functions of fish. They work to control these functions by reducing the production of natural sex steroids and the secretion hormones of the pituitary gland, which have a big role in the maturity and development of the gonads, affecting the quality of the gametes formed and the consequences on embryos and births ${ }^{[30,31]}$.

The effect of the ovaries treated with temperature (high and low) and Hydrocortisone in the current study differed. Some of the ovaries appeared to contain large numbers of eggs, but they were not developed and others appeared to contain embryos and undeveloped eggs, while others appeared to contain developed, but dead, embryos. However, it may be due to the time when treatment occurred during the developmental stage of the fish's ovary as it entered the experiment and the sensitivity of each developmental stage of the ovaries to temperature and Hydrocortisone.

The external cortisol, which is given to fish, increases the cloning of the gene responsible for the formation of the yolk in the liver, which increases the production of the yolk masses. However, this increase is not accompanied by the development of plasmid yolk in fish treated with this hormone ${ }^{[32]}$. It was noticed in Semelparous pacific Salmon where there was an increase in cortisol levels, this state is called hypercortisolism, which may cause death to eggs after ovulation ${ }^{[33]}$. This explains the number of ovaries treated in the current experiment, which were found to be containing a number of undeveloped and semi-decayed eggs due to the impact of hydrocortisone on them.

Cortisol is necessary at certain levels of egg development. It has been found that it moves to the egg cells during the process of yolk formation (vitellogenesis) in fish in order to ensure the early development of eggs ${ }^{[34,35,36]}$, and then it becomes less important in the embryonic stage (Embryogenesis), so the presence of this hormone at abnormal levels during the process of embryonic formation leads to disrupt or inhibit the development of embryos in addition to the low survival rate in births resulted from the embryos exposed to abnormal levels of cortisol ${ }^{[37,38]}$. This result coincided with what was observed in the results of the current experiment of the presence of embryos whose development did not complete and the high percentage of deaths of the developed embryos.

\section{CONCLUSION}

1. The limitedness of sexual transformation in female X. helleri matured to males on the external appearance only and specifically the emergence of the sword, with significant changes in female gonads.

2. The role of hydrocortisone in the current study is very clear as it is regarded as a catalyst in sexual transformation at different temperatures in summer and winter.

The current study concluded, the hydrocortisone act as a promote to sexual transformation under different temperatures. This sexual transformation is done on the one of external features only, that is emeregence the sword in femals.

\section{CONFLICTS OF INTEREST}

There are no conflicts of interest.

\section{REFERENCES}

1. Devlin, R. H. and Nagahama, Y.(2002). Sex determination and sex differentiation in fish: an overview of genetic, physiological and environmental influences. Aqu.; 208:191-364.

2. Waters, P. D.; Wallis, M. C. and Graves, J. A. M.(2007). Mammalian sex - Origin and evolution of the Y chromosome and SRY . Semin. Cell Dev. Biol., 18: 389-400.

3. Baroiller, JF.; Guiguen, Y. and Fostier, A.(1999). Endocrine and environmental aspects of sex differentiation in fish. Cell Mol. Life Sci., 55:910-931.

4. Romer, U. and Beisenherz, W.(1996). Environmental determination of sex in Apistogramma (Cichlidae) and 2 other fresh- water fishes (Teleostei) . J. Fish Biol.,48: 714-725.

5. Krueger, W. H. and Oliveira, K.(1999). Evidence for Environmental Sex Determination in the American ell, Anguilla rostrata. Environ. Biol. Fishes. 55: 381-389.

6. Piferrer, F.; Blázques, M.; Navarro, L. and González, A.(2005). Genetic, endocrine and environmental components of sex determination and differentiation in the European sea bass Dicentrarchus labrax L. . Gen. Comp. Endocrinol., 142:102-110.

7. Tabata, K.(1995). Reduction of female proportion in lower growing fish separated from normal and feminized seedlings of hirame Paralichthys olivaceus . Fish Sci.,61:199-201.

8. Kitano, T.; Takamune, K.; Nagahama, Y. and Abe, S.(2001). Role of P450 aromatase in gonadal sex differentiation in Japanese flounder (Paralichthys olivaceus) . Environ. Sci..8:1-11.

9. Nakamura, M. and Kobayashi, Y.(2005). Sex change in coral reef fish. Fish phy. and Bioc., 31:117-122. 
10. Godwin, J.(2009).Social determination of sex in reef fishes. Semin. Cell Dev. Biol., 20:264-270.

11. Zanuy, S.; Carrillo, M.; Felip, A.; Rodríguez, L.; Blázquez, M. and Ramos, J.(2001). Genetic, hormonal and environmental approaches for the control of reproduction in the European sea bass Dicentrarchus labrax L. . Aqu., 202: 187-203.

12. Angus, R. A. and Peoples, S. D.(2001). Gonopodium development in normal male and 11- Ketotestosterone treated female Mosquitofish (Gambusia affinis) : A quantitative study using computer Figure analysis. Endo.,123, (2): 222-234.

13. Nepomnaschy, PA.; Welch, KB.; McConnell, DS.; Low, BS.; Strassmann, BI. And England, BC.(2006). Cortisol levels and very early pregnancy loss in humans. Proceedings of the National Academy of Sciences of the United States of America, 103: 3938-3942.

14. Whirledge, S. and Cidlowski, JA.(2010). Glucocorticoids, Stress and Fertility. Min. Endo., 35:109-125.

15. Al-saimary, A.S.(2018). Effect of hydrocortisone hormone on the bone tissue differentiation and some histological and physiological changes in females mice Mus musculus L. P.H.D. thesis, Basra University/ Collage of Education for Pure Science, 217p.

16. Yamaguchi, T.; Yoshinaga, N.; Yazawa, T.; Gen, $\mathrm{K}$. and Kitano, T.(2010). Cortisol is involved in temperature - dependent sex determination in the Japanese flounder. Endo. ; 151: 3900-3908.

17. Mazloumi, N.; Amiri, B. M.; Nematollahi, M. and Rafieem G.(2015). Hydrocortisone treatment may enhance survival and stocking of Beluga sturgeon (Huso huso Linnaeus, 1758) in estuaries of the Caspian Sea. Inter. J. Aqua. Bio.,3(3):129-134.

18. Humason, G. L.(1972). Animal tissue techniques. $3^{\text {rd }}$ ed. W. h. Freeman and Company, son fran, 614p.

19. Weinbery,S.L. and Abramowitz,S.K. (2015). Statistics using Spss: An integrative approach, $3^{\text {ed }}$. Cambridge university press, $\mathrm{p} 592$.

20. Dranow, D.B.; Tucker, R.P. and Draper, B.W.(2013). Germ cells are required to maintain a stable sexual phenotype in adult zebrafish. Dev. Biol., 376 :43-50.

21. Kobayashi,Y.; Nagahama,Y. \& Nakamura,M. (2013). Diverstity and plastisicity of sex determination and differentiation in fishes. Sexual Develop.,7:115-125.

22. Ozaki, Y.; Higuchi, M.; Miura, C.; Yamaguchi, S.; Tozawa, Y. and Miura, T.(2006). Roles of 11 beta-hydroxysteroid dehydrogenase in fish spermatogenesis. Endo., 147: 5139-5146.

23. Perry, AN. And Grober, MS.(2003). A model for social control of sex change: interactions of behavior, neuropeptides, glucocorticoids, and sex steroids. Horm. and Beh., 43:31-38.
24. Liu, H.; Todd, EV.; Lokman, PM.; Lamm, MS. Godwin, JR and Gemmell, NJ.(2017). Sexual plasticity: A fishy tale. Mol. Rep. and Dev., 1-24.

25. Todd, E.V.; Liu, H.; Muncaster, S. and Gemmell, N.J. (2016). Bending genders: The biology of natural sex change in fish. Sex. Dev., 10: 223-241.

26. Hayashi, Y.; Kobira, H.; Yamaguchi, T.; Shiraishi, E.; Yazawa, T.; Hirai, T.; Kamei, Y. and Kitano, T.(2010). High temperature causes masculinization of genetically female medaka by elevation of cortisol. Mol. Rep. and Dev., 77: 679-686.

27. Hattori, RS.; Fernandino, JI.; Kishii, A.; Kimura, H.; Kinno, T.; Oura, M.; Somoza, GM.; Yokota, M.; Strüssmann, CA. and Watanabe, S.(2009). Cortisol- induced Masculinization : Dose thermal stress affect gonadal fate in pejerrey, a teleost fish with temperature- dependent sex determination? PLoS One 4.

28. Nozu, R. and Nakamura, M.(2015).Cortisol administration induces sex change from ovary to testis in the protogynous Wrasse, Halichoeres trimaculatus. Sex Dev.,9:118-124.

29. Solomon-Lane, TK.; Crespi, EJ. And Grober, MS.(2013). Stress and serial adult metamorphosis: multiple roles for the stress axis in socially regulated sex change. Front Neurosci , $7: 210$.

30. Compbell, PM; Pottinger, TG and Sumpter, JP.(1994). Preliminary evidence that chronic confinement stress reduces the quality of gametes produced by brown trout. Aqu., 120: 151.

31. Carragher, JF and Sumpter, JP (1990). The effect of cortisol on the secretion of sex steroids from cultured ovarian follicles of rainbow trout. Gen Comp Endocrinol., 77: 403.

32. Ding, J.L.; Lim, E.H. and Lam, T.J. (1994). Cortisol induced hepatic vitellogenin mRNA in Oreochromis aureus (Steindachner). Gen.Comp. Endocrinol., 96: 276

33. Sten-Behrens, B.A. and Sapolsky, R.M. (1992). Stress glucocorticoids and aging. Aging. Clin. Exp. Res., 4: 197.

34. Tagawa, M.; Suzuki, K. and Specker, JL.(2000). Incorporation and metabolism of cortisol in oocytes of tilapia (Oreochromis mossambicus). J. Exp. Zool., 287: 485-492.

35. Mommsen, TP. and Walsh, PJ.(1988). Vitellogenesis and oocyte assembly. In Fish physiology V11A (eds WS Hoar, DJ Randall), pp.247-406.

36. Nesan, D. and Vijayan, MM.(2012). Embryo exposure to elevated cortisol level leads to cardiac performance dysfunction in zebrafish. Mol. Cell Endocrinol., 363:85-91. 
37. Hillegass, JM. ; Villano, CM.; Cooper, KR. and White, LA.(2008). Glucocorticoids alter craniofacial development and increase expression and activity of matrix metalloproteinases in developing zebrafish (Daniorerio) . Toxicol. Sci., 102:413-424.
38. Hillegass, JM.; Villano, CM.; Cooper, KR. And White, LA. Glucocorticoids alter craniofacial development and increase expression and activity of matrix metalloproteinases in developing zebrafish (Danio rerio). (2012). Toxicol.Sci., 102:413-424. 
الملخص العربى

\section{تحول جنسي في سمكة السيف Xiphophorues helleri تحث تأثير هيدروكورتيزون هرمون ودرجة الحرارة}

\section{على عبد اللطيف عبد الحسن العلي و منيرة إبراهيم عبدالله

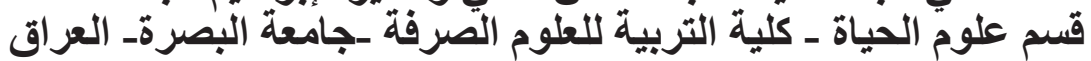

Genetic Sex يحدد الجنس في الفقريات بصورة عامة بواسطة أثنين من الأليات ها تحديد الجنس ور اثيا و وتحديد الجنس بيئيا (Determination (GSD الدور الذي تؤديه الهرمونات ، كالهرمونات القشرية في هذه العملية . تم الحصول على أسماك X. helleri الناضجة من محلات بيع أسماك الزينة في محافظة البصرة . صممت التجارب من خلال أجر اء تجربتين تضمنت كل منها 40 سمكة ،الأولى في فصل الصيف من 30 تموز 2017 لغاية 28أب 2017 تحت درجة حرارة المختبر التي تراوحت

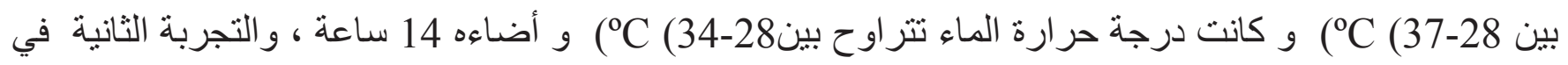
فصل الثتاء من 3 كانون الأول 2017ولغاية 2 كانون الثاني 2018 تحت درجة حرارة مختبر

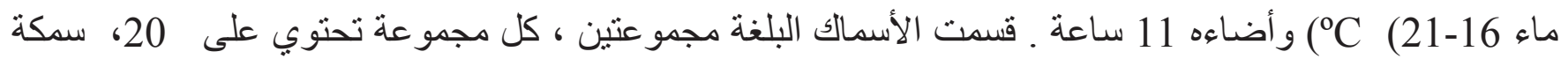
12 أنتى و 8 ذكور ، وضعت في احو اض زجاجية سعة 60 لتر مزودة بأجززة تهوية ومحر ار لقياس درجة حرارة الماء ، عدت المجموعة الاولى كمجموعة سيطرة لكل من تجربة فصل الصيف و تجربة فصل الثتاء ، في حين عydrocortisone Sodium Succinate علت اسماك المجموعة الثانية لمدة شهر بهرمون الهيدروكورتيزون

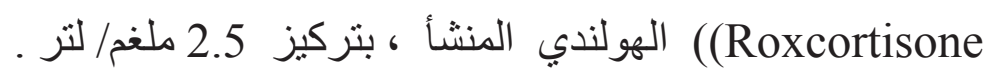
بينت نتائج الدر اسة الحالية حدوث تغير ات مظهرية في أناث سمكة X. helleri المعاملة بهرمون الهيدروكورتيزون

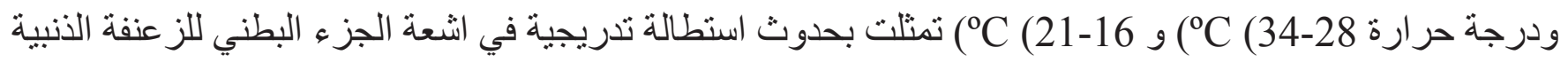
،اذ بلغت الاستطالة فيها حد المعنوية بين إناث المجمو عة المعاملة صيف وشتاء على التو الي مع إناث مجمو عة السيطرة

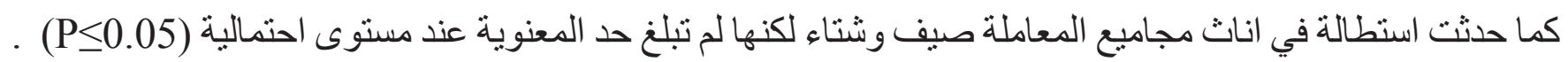
كما تأثرت مبايض الإناث من حيث حجمها ومحتوياتها وتركيبها ، إذ أظهرت نتائج الفحص المجهري لمبايض سمكة المعاملة بهرمون الهيدروكورنيزون و درجة حرارة 28- helleri اعداد كبيرة من البيوض الضامرة Atrophy ، و مبايض احتوت على بيوض واجنة متحللة ، في حين كانت مبايض اخرى حاوية على اجنة مكتملة النمو لكنها ميتة . اما مبايض اناث المجموعة المعاملة بهرمون الهيدروكورتيزون ودرجة حر ارة 16-C (21) فتميزت أجنتها العديدة ، التي ظهرت في المبايض ، بأنها ميتة وبعضها ظهرت بشكا اجنة ذات تتو هات خلقية متتو عة فمنها من ظهر ذي رأس منتفخ في المنطقة الققوية، ولوحظ ايضا أن بعض الأجنة ذات التو اءات في مناطق مختلفة من العمود الفقري. وخلصت الدراسة الحالية إلى أن الهيدروكورتيزون يعمل على تعزيز التحول الجنسي في درجات حرارة مختلفة. يتم هذا التحول الجنسي على إحدى الصفات الخارجية فقط ، أي ظهور 